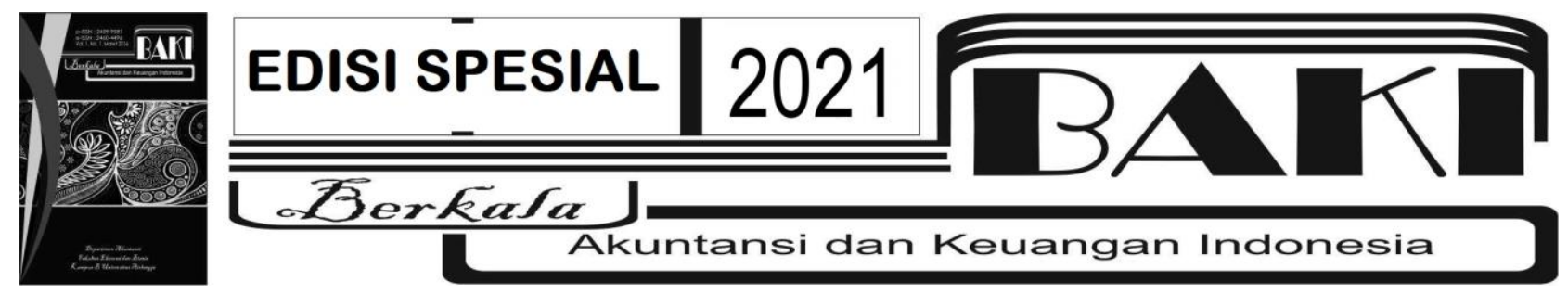

\title{
THE INFLUENCE OF THE TOURISM SECTOR ON ECONOMIC GROWTH AND ITS EFFECT ON MICRO AND SMALL ENTERPRISES (UMK) IN Yogyakarta
}

\section{PENGARUH SEKTOR PARIWISATA TERHADAP PERTUMBUHAN EKONOMI DAN EFEKNYA KEPADA USAHA MIKRO KECIL (UMK) DI YOGYAKARTA}

\section{Oelistina $^{1}$}

\section{${ }^{1}$ Badan Pusat Statistik Provinsi Jambi}

lubabah15@gmail.com

INFOARTIKEL

Histori Artikel:

Tanggal Masuk 27 Mei 2021

Revisi Diterima 11 Juni 2021

Tanggal Diterima 15 Juli 2021

Tersedia Online 31 Juli 2021

Keywords: Micro and Small Business, The Covid-19 Pandemic, Tourism
Kata Kunci: Pandemi Covid19, Pariwisata, Usaha Mikro Kecil

\section{$A B S T R A C T$}

Yogyakarta's economic growth contracted by up to 6.74 percent (Quarter II 2020). This is due to the declining growth of the tourism sector as the driving sector for Yogyakarta's economy. Even though the tourism sector is the lifeblood of Micro and Small Enterprises (UMK). As many as 75.09 percent of Micro and Small Enterprises are businesses that surround the Yogyakarta tourism sector which is usually invaded by tourists. The purpose of this research is to look at the impact of the tourism sector on economic growth and link it to Micro and Small Enterprises. The results of the Mc Nemar statistical test stated that the covid-19 pandemic affected Yogyakarta's economic growth with a significance of 0.021 . The results of the F-test indicate that the tourism sector (represented by Room Occupancy Rate variable $\left(X_{1}\right)$ and foreign guest visits $\left(X_{2}\right)$ ) affect economic growth $(Y)$ with a significance of less than 0.05 . The results of the quantitative descriptive analysis also add information that there are 3 Micro and Small Enterprises that play an important role in Yogyakarta tourism, namely: the food industry, the weaving industry, and the apparel industry (batik craft).

\section{A B STRAK}

Pertumbuhan ekonomi Yogyakarta terkontraksi hingga 6,74 persen (Triwulan II 2020). Hal ini disebabkan menurunnya pertumbuhan sektor pariwisata sebagai sektor penggerak perekonomian Yogyakarta. Padahal sektor pariwisata merupakan tumpuan hidup 
Usaha Mikro Kecil (UMK). Sebanyak 75,09 persen Usaha Mikro Kecil merupakan usaha yang berada di sekitar sektor pariwisata Yogyakarta yang biasanya diserbu wisatawan. Tujuan penelitian ini akan melihat pengaruh sektor pariwisata terhadap pertumbuhan ekonomi dan menghubungkannya dengan Usaha Mikro Kecil. Hasil Uji statistik Mc Nemar menyebutkan bahwa pandemi covid-19 mempengaruhi pertumbuhan ekonomi Yogyakarta dengan signifikansi 0,021. Hasil uji $F$ menyebutkan sektor pariwisata (diwakili variabel Tingkat Penghunian Kamar $\left(X_{1}\right)$ dan kunjungan tamu mancanegara $\left(\mathrm{X}_{2}\right)$ ) mempengaruhi pertumbuhan ekonomi $(\mathrm{Y})$ dengan signifikansi kurang dari 0,05. Hasil analisis deskriptif kuantitatif juga menambah informasi ada 3 Usaha Mikro Kecil yang berperan penting dalam pariwisata Yogyakarta yaitu : usaha industri makanan, industri anyaman dan industri pakaian jadi (kerajinan batik).

Berkala Akuntansi dan Keuangan Indonesia p-ISSN: 2459-9581; e-ISSN 2460-4496

DOI: 10.20473/baki.vxix.27085

Open access under Creative Common Attribution-Non Commercial-Share A like 4.0 International Licence (CC-BY-NC-SA)@(@)

\section{Pendahuluan}

Pada triwulan pertama tahun 2020, pertumbuhan ekonomi Yogyakarta mengalami kontraksi (minus 0,17 persen) (BPS Provinsi DIY Yogyakarta, 2020). Laju pertumbuhan tersebut paling rendah kedua secara nasional (Gambar 1). Pandemi covid-19 sangat mempengaruhi perekonomian Provinsi Yogyakarta. Padahal kasus pertama covid-19 ditemukan pada Maret 2020, namun langsung berimbas pada kondisi ekonomi triwulan I 2020.

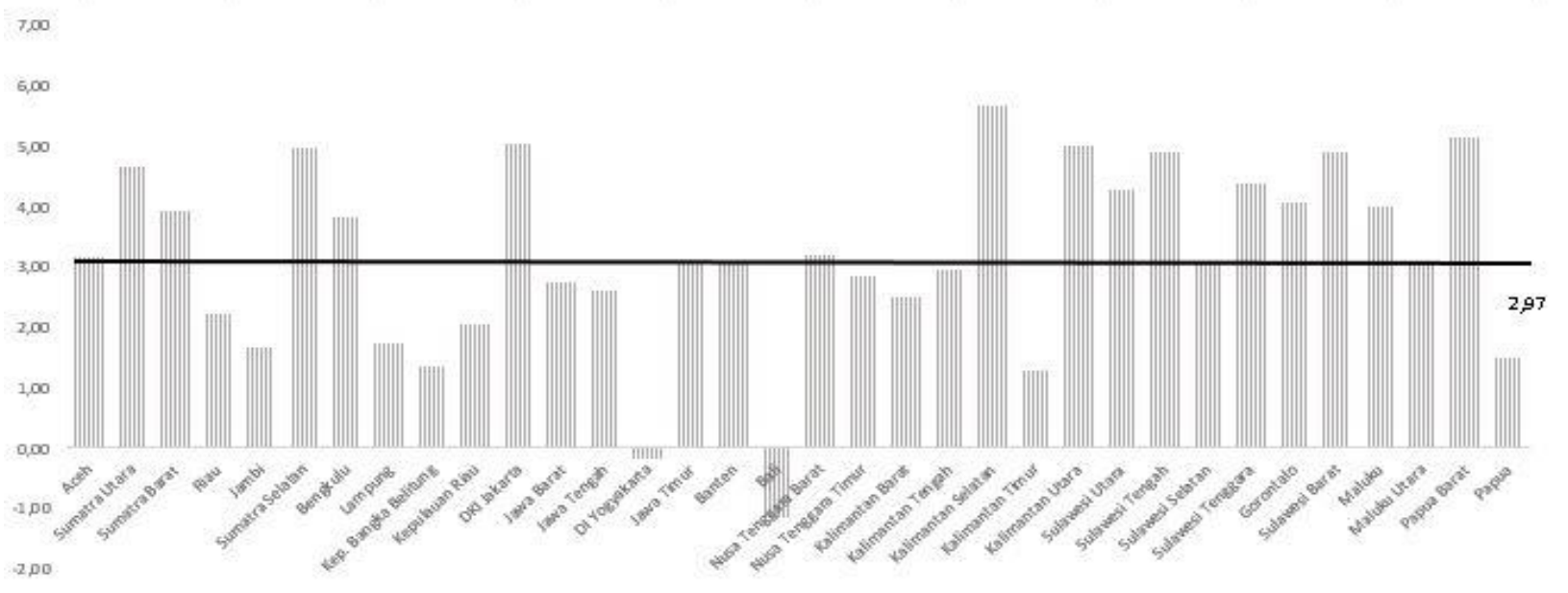

Gambar 1

\section{Laju Pertumbuhan Ekonomi menurut Provinsi se-Indonesia, Q1 2020}

Sumber: data diolah, 2020

Perkembangan perekonomian semakin mengkhawatirkan pada saat memasuki triwulan II 2020. Ketika laju pertumbuhan ekonomi Indonesia minus hingga 5,32 persen, Provinsi 
Yogyakarta terkontraksi 6,74 persen. Demikian dalam pandemi covid-19 mempengaruhi perekonomian Provinsi Yogyakarta. Terganggunya perekonomian Yogyakarta akan berdampak pada kondisi usaha dan bisnis khususnya UMK yang dominan di Provinsi Yogyakarta .

Selama ini Yogyakarta dikenal sebagai kota bisnis, wisata dan pendidikan (Supriyadi et al., 2020). Bisnis ekonomi yang dapat mendukung sektor pariwisata, karena Yogyakarta merupakan tujuan wisata terbesar kedua di Indonesia setelah Bali (Sari \& Aliyah, 2021).

Begitu juga dengan julukan kota pendidikan yang disematkan ke kota ini membuat Yogyakarta memiliki magnet yang menarik minat pelajar dan pendatang seluruh Indonesia untuk mencari ilmu kesana (Sugiyanto, 2004). Wisatawan maupun pelajar yang datang ke Yogyakarta apabila pulang ke kampung halaman akan membawa cinderamata dan oleh-oleh yang dihasilkan oleh UMK (Suryadinata, 2017).

Tingginya output dari industri pengolahan makanan yang dihasilkan UMK akan terserap oleh wisatawan yang datang ke Yogyakarta. Wisata kuliner menjadi salah satu alternatif bagi wisatawan selain memilih wisata budaya, wisata alam dan wisata bahari (Besra, 2012). Penelitian lain juga menyimpulkan bahwa perkembangan wisata belanja oleh-oleh makanan didukung oleh perkembangan UMK makanan dan adanya minat wisatawan terhadap makanan tersebut (Sunaryo et al., 2019). Jumlah mahasiswa dari luar kota dapat membuat industri pengolahan makanan tumbuh subur. Makanan khas merupakan buah tangan yang bisa dibawa pulang ke tempat asal (Yuliana, 2017).

Ketika pandemi covid-19 datang, kondisi wisata Yogyakarta berubah. Sektor pariwisatanya mulai menurun. Pembatasan sosial dan perjalanan ke tempat umum dibatasi. Pemerintah pusat melarang pesawat komersil untuk terbang hingga 1 Juni 2020 (Djausal et al., 2020). Menurunnya pergerakan manusia ke Yogyakarta terpotret dalam data penumpang di bandara Adi Sucipto tepatnya di pintu kedatangan. Pada triwulan pertama tahun 2020 kunjungan wisatawan mancanegara mencapai 18.633 orang, namun memasuki triwulan kedua 2020 hanya 7 orang yang datang lewat bandara Adi Sucipto (BPS Provinsi D.I Yogyakarta, 2020a).

Sektor pariwisata sangat rentan terhadap pergerakan manusia (Gössling et al., 2020). Akibat pembatasan pergerakan (sosial distancing) akan berdampak pada pariwisata (Pak et al., 2020) dan membuat perekonomian semakin buruk. Pendapatan UMK pun ikut menurun akibat berkurangnya wisatawan yang datang ke Yogyakarta (Berita satu.com, 2020).

Tidak dapat dipungkiri antara sektor pariwisata, pertumbuhan ekonomi dan UMK memiliki hubungan (Sanaubar et al., 2017). Tujuan penelitian ini adalah untuk melihat pengaruh sektor pariwisata terhadap perekonomian Yogyakarta dan efeknya terhadap keberadaan UMK selama pandemi covid-19 melanda. Hubungan antara pariwisata dan ekonomi mengacu kepada penelitian di Malaysia yang menunjukkan bahwa pariwisata mempengaruhi pertumbuhan 
ekonomi (Tang, C. F., \& Tan, E. C., 2015). Sehingga setiap keadaan yang mempengaruhi pariwisata akan berdampak pada pertumbuhan ekonomi.

\section{Tinjauan Pustaka}

Wisatawan Mancanegara

Konsep dan definisi wisatawan mancanegara mengacu pada rekomendasi World Tourism Orgnization (WTO) milik Perserikatan Bangsa-Bangsa. Wisatawan mancanegara merupakan setiap individu yang melakukan perjalanan ke suatu wilayah di luar tempat tinggalnya, dengan periode waktu kurang dari satu tahun dengan sebuah tujuan utama. Tujuan disini baik untuk bisnis, berlibur maupun tujuan lainnya selain untuk bekerja dengan penduduk negara yang dikunjungi. Dua kategori tamu/wisatawan yaitu :

a. Wisatawan (tourist)

Tourist adalah setiap pengunjung seperti definisi di atas yang tinggal paling sedikit 24 jam, akan tetapi tidak lebih dari 12 bulan di tempat yang dikunjungi dengan maksud kunjungan antara lain :

> Personal, yaitu berlibur, rekreasi, mengunjungi teman atau keluarga, belajar atau pelatihan, kesehatan dan olahraga, keagamaan, belanja, transit dan lain-lain.

$>$ Bisnis dan professional, yaitu menghadiri pertemuan, konferensi atau kongres, pameran dagang, konser, pertunjukkan dan lain-lain.

b. Pelancong (excursionist)

Pelancong merupakan setiap pengunjung seperti definisi di atas namun tinggal kurang dari 24 jam di tempat yang dikunjungi, termasuk cruise passenger yaitu setiap pengunjung yang tiba di suatu negara dengan kapal atau kereta api, dimana mereka tidak menginap di akomodasi yang tersedia di negara tersebut (BPS, 2020).

Tingkat Penghunian Kamar (TPK)

Merujuk definisi yang dianut oleh Badan Pusat Statistik dalam sirusa.bps.go.id bahwa Tingkat Penghunian Kamar hotel atau biasa dikenal dengan TPK hotel merupakan perbandingan antara banyaknya malam kamar yang terpakai dengan banyaknya malam kamar yang tersedia. Satuan untuk TPK adalah persentase, dirumuskan sebagai berikut :

$$
T P K=\frac{A}{B} \times 100
$$

\section{Dimana :}

TPK = Tingkat Penghunian Kamar (satuan persen)

A $\quad=$ Jumlah malam kamar yang dihuni 
$=$ Jumlah malam kamar yang tersedia

Manfaat penghitungan TPK adalah memberikan gambaran berapa persen kamar yang tersedia pada akomodasi yang terisi oleh tamu yang menginap dalam suatu waktu tertentu dan menunjukkan apakah suatu akomodasi diminati oleh pengunjung/wisatawan atau tidak, sehingga dapat dilihat apakah di suatu daerah masih kurang keberadaan akomodasi atau tidak untuk memenuhi kebutuhan masyarakat dan wisatawan (BPS, 2020).

\section{Pertumbuhan Ekonomi}

Badan Pusat Statistik di website sirusa.bps.go.id mencatatkan pertumbuhan ekonomi sebagai perkembangan produksi barang dan jasa pada suatu regional perekonomian periode tahun tertentu terhadap nilai tahun sebelumnya yang dihitung berdasarkan Produk Domestik Regional (PDB) atau Produk Domestik Regional Bruto (PDRB) atas dasar harga konstan (BPS, 2020).

Kuznet mengemukakan pertumbuhan ekonomi merupakan proses jangka panjang dari meningkatnya kapsitas produksi suatu negara untuk menyediakan barang-barang ekonomi bagi warganya. Model pertumbuhan ekonomi neoklasik menurut Solow menunjukkan stok modal, tenaga kerja dengan asumsi bahwa produksi yang konstan akan mempengaruhi jumlah output barang dan jasa. Model pertumbuhan Solow juga dirancang untuk menentukan apakah tingkat tabungan, persediaan modal, tingkat populasi, dan kemajuan teknologi berdampak pada pertumbuhan ekonomi. Aspek utama pertumbuhan ekonomi adalah: pertumbuhan output total dan pertumbuhan laju penduduk (Gaol, 2003).

Penelitian mengenai korelasi antara sektor pariwisata dengan pertumbuhan ekonomi sudah banyak dilakukan. Penelitian tentang pengaruh pariwisata terhadap pertumbuhan ekonomi di Kota Sabang. Hasil kajiannya menyebutkan variabel jumlah kunjungan wisatawan mancanegara, jumlah kunjungan wisatawan nusantara, jumlah lokasi wisata dan TPK signifikan terhadap pertumbuhan ekonomi (Sakhibul, 2017). Penelitian tentang kualitas produk serta obyek wisata mempengaruhi kepuasan wisatatawan sehingga meningkatkan pendapatan asli daerah (Kalebos, 2016). Ada juga penelitian terdahulu yang menggunakan analisis jalur (path analysis) untuk mengetahui hubungan antara kunjungan wisata, TPK dan pengeluaran wisatawan terhadap penyerapan tenaga kerja (Windayani \& Sri Budhi, 2017).

Sedangkan penelitian pandemi covid-19 dan pengaruhnya terhadap pariwisata antara lain penelitian mengenai pentingnya mengubah strategi pemasaran hotel di tengah lesunya sektor pariwisata akibat pandemi covid-19 (A. Masatip., 2020). Banyaknya hotel dan tempat wisata yang tutup di Provinsi Bali akibat pandemi covid-19 (Kusuma, 2020).

Pengembangan Hipotesis 
Pandemi covid-19 memaksa orang untuk memberlakukan protokol kesehatan secara ketat dimanapun. Memakai masker, mencuci tangan dan menjaga jarak (sosial distancing) termasuk menghindari kerumunan. Pembatasan sosial ini mengakibatkan sektor transportasi mengalami perlambatan (Audy \& Irfan, 2021).

Untuk mengurangi penyebaran virus, pemerintah menghentikan beberapa penerbangan, perjalanan wisata dan kegiatan yang dianggap menambah kasus covid-19. Rutinitas kegiatan sehari-hari pun terpaksa dilakukan dari rumah seperti Work From Home (WFH), School From Home (SFH) dan beribadah. Akibatnya, sektor ekonomi pun mengalami perlambatan bahkan kontraksi hingga pada posisi pertumbuhan ekonomi minus (Alwandi \& Muchlisoh, 2021). Berdasarkan hasil penelitian tersebut maka dirumuskan hipotesis pertama sebagai berikut :

$\mathrm{H}_{1}$ : Terdapat perubahan kondisi pertumbuhan ekonomi Provinsi Yogyakarta sebelum dan sesudah terjadinya pandemi covid-19

Pariwisata merupakan sektor unggulan Yogyakarta. Peran pariwisata dan sektor pendukungnya menduduki posisi paling penting dalam perekonomian Yogyakarta (Saputra \& Kurniawan, 2012). Perhotelan merupakan salah satu sektor pendukung pariwisata. Hotel dan restoran mampu menyerap tenaga kerja dalam jumlah banyak dan berkontribusi positif terhadap kegiatan ekonomi di sekitar obyek wisata (Akouino, 2013).

Sektor pariwisata bergantung pada jumlah kunjungan wisatawan terutama wisatawan mancanegara (Maulana, 2016). Demikian halnya dengan TPK dan jumlah wisatawan mancanegara akan berpengaruh kepada pendapatan sektor pariwisata nasional (Munanda.R, 2019). Berdasarkan hal tersebut, penelitian ini akan menguatkan argumen dengan mengambil dua hipotesis sekaligus sebagai berikut :

$\mathrm{H}_{2}$ : Secara simultan variabel TPK hotel bintang $\left(\mathrm{X}_{1}\right)$ dan jumlah wisatawan mancanegara $\left(\mathrm{X}_{2}\right)$ yang mengunjungi Provinsi Yogyakarta berpengaruh terhadap pertumbuhan ekonomi Provinsi Yogyakarta

$\mathrm{H}_{3}$ : Secara parsial variabel TPK hotel bintang $\left(X_{1}\right)$ dan jumlah wisatawan mancanegara $\left(X_{2}\right)$ yang mengunjungi Provinsi Yogyakarta berpengaruh terhadap pertumbuhan ekonomi Provinsi Yogyakarta

\section{Metodologi Penelitian}


Penelitian ini menggunakan satu alat uji dan dua analisis yaitu uji statistik Mc Nemar dan analisis regresi linier berganda serta analisis deskriptif kuantitatif. Pembahasan singkat mengenai ketiga instrumen penelitian adalah sebagai berikut :

\subsection{Uji Statistik Mc Nemar}

Uji statistik Mc Nemar mengasumsikan 3 hal yaitu : data tidak harus bersifat normal, ada dua variabel berhubungan dan nilai data bersifat dikotomi/berlawanan (Wahdini et al., 2009). Uji statistik Mc Nemar merupakan uji non parametrik dan bisa diterapkan pada data nominal atau ordinal. Uji statistik Mc Nemar berfungsi untuk melihat hasil suatu perlakuan/keadaan (Putra \& Saskara, 2013). Data yang disajikan dalam penelitian ini merupakan data sekunder dari Badan Pusat Statistik Provinsi Daerah Istimewa Yogyakarta. Data diperoleh dengan mengakses laman resmi yogyakarta.bps.go.id.

Variabel yang diamati merupakan laju pertumbuhan ekonomi ( $y$ on $y$ ) pada 17 kategori dalam Produk Domestik Regional Bruto (PDRB) lapangan usaha. Triwulan kedua tahun 2019 sebagai kondisi sebelum pandemi dan triwulan kedua tahun 2020 sebagai kondisi sesudah pandemi covid-19 (pertumbuhan ekonomi $y$ on $y$ ).

Pengolahan uji statistik Mc Nemar dilakukan dengan bantuan SPSS versi 25. Pengolahan variabel pertumbuhan ekonomi dengan perlakuan data bernilai minus akan disimbolkan dengan "negatif" dan berlaku data nilai tidak minus akan disimbolkan "positif". Kesimpulan yang didapatkan berupa uji signifikansi terhadap variabel. Apabila signifikansi kurang dari 0,05 maka bisa disimpulkan bahwa perlakuan/keadaan terhadap suatu obyek/variabel memang berpengaruh.

Jika signifikansi lebih dari 0,05 artinya hipotesis satu diterima, terdapat perubahan kondisi variabel antara sebelum dan sesudah terjadinya perlakuan/keadaan. Perlakuan atau keadaan yang dimaksud adalah pandemi covid-19, periode triwulan kedua tahun 2019 belum terjadi pandemi covid19 sementara triwulan kedua tahun 2020 Yogyakarta sudah mengalami pandemi covid-19.

\subsection{Analisis Regresi Linier Berganda}

Alat kedua dalam penelitian ini merupakan analisis inferensia yang lebih dikenal dengan sebutan analisis regresi linier berganda. Analisis ini akan mengukur hubungan antara beberapa variabel. Analisis regresi linier berganda mempunyai 5 asumsi yaitu : normalitas, multikolinieritas, homoskedastisitas, autokorelasi dan uji simultan/uji $\mathrm{F}$ maupun uji parsial/uji $\mathrm{t}$ (Ningsih \& Dukalang, 2019).

Regresi linier berganda dalam kajian ini digunakan untuk mengukur pengaruh sektor pariwisata yang dalam hal ini diwakili oleh variabel TPK hotel bintang $\left(X_{1}\right)$ dan jumlah kunjungan wisatawan mancanegara ke Yogyakarta $\left(\mathrm{X}_{2}\right)$ terhadap pertumbuhan ekonomi $(\mathrm{Y})$. Periode penelitian diambil data dari triwulan satu tahun 2017 hingga triwulan ketiga tahun 2020. Data yang diolah merupakan laju pertumbuhan ekonomi triwulanan ( $y$ on $y$ ), TPK dan jumlah kunjungan wisatawan mancanegara 
bulanan yang bisa diperoleh dari Berita Resmi Statistik (BRS) Badan Pusat Statistik Provinsi Yogyakarta dengan mengakses yogyakarta.bps.go.id.

\subsection{Analisis Deskriptif Kuantitatif}

Analisis deskriptif kuantitatif dengan pengamatan terhadap UMK di Yogyakarta dari Publikasi Profil Industri Mikro dan Kecil Daerah Istimewa Yogyakarta tahun 2019 dan hasil survei IMK Tahunan BPS Provinsi Yogyakarta. Analisis deskriptif kuantitatif memfokuskan pada suatu variabel tanpa menghubungkannya dengan variabel lain (Yane et al., 2017). Analisis ini akan mengamati data dari sisi jumlah, rangking maupun persentasenya (Faelasofi, 2017). Fokus yang diamati adalah data laju pertumbuhan ekonomi dan UMK di Yogyakarta.

Jadi penelitian ini tidak menggunakan data primer. Kajian difokuskan pada data sekunder yang diperoleh dari BPS Provinsi Daerah Istimewa Yogyakarta berupa data TPK, jumlah kunjungan wisatawan mancanegara, pertumbuhan ekonomi dan jumlah UMK. Pengambilan sampel tidak dilakukan, hanya sekedar melakukan uji statistik pada variabel yang diamati. Uji statistik Mc Nemar dirasakan penting untuk membuktikan kebenaran bahwa memang pandemi covid-19 mempengaruhi pertumbuhan ekonomi Yogyakarta.

\section{Hasil dan Pembahasan}

\subsection{Hasil Uji Statistik Mc Nemar}

Memasuki triwulan kedua tahun 2020 perekonomian Yogyakarta terkontraksi dalam, laju pertumbuhan ekonominya mencapai minus 6,74 persen (BPS Provinsi D.I Yogyakarta, 2020b) . Diperlukan pembuktian empiris dengan uji statistik Mc Nemar untuk dapat membandingkan kondisi sebelum dan sesudah pandemi covid-19 melanda agar bisa ditarik kesimpulan bahwa pandemi covid-19 memang memengaruhi pertumbuhan ekonomi Yogyakarta. Hal ini penting, karena dengan mengetahui pengaruh secara statistik dan ilmiah berdasar data maka dapat dibuktikan kebenaran sebuah pernyataan.

Hasil uji perbandingan menghasilkan signifikansi sebesar 0,021 (dibawah 0,05). Artinya bahwa pandemi covid-19 memang sangat memengaruhi pertumbuhan ekonomi Provinsi Yogyakarta. Dari tabel silang yang dihasilkan oleh pengolahan SPSS dapat diperoleh bahwa ada 9 kategori yang pertumbuhan ekonominya berubah menjadi minus sesudah pandemi. Sedangkan kategori yang berubah dari negatif menjadi positif hanya satu yaitu kategori pertanian, kehutanan dan perikanan.

Tabel 1

Hasil Pengolahan Uji Statistik Mc Nemar terhadap Kategori Lapangan Usaha

\begin{tabular}{lcccc}
\hline \multicolumn{1}{c}{$\begin{array}{l}\text { Sebelum } \\
\text { Pandemi }\end{array}$} & \multicolumn{2}{c}{ Sesudah Pandemi } & Jumlah & Nilai Exact Sign \\
\cline { 2 - 4 } Positif & Positif & Negatif & $\mathbf{N}$ & \\
Negatif & 7 & 0 & -17 & 0,021 \\
Signifikansi & 1 & & 17 \\
\hline
\end{tabular}

Sumber: data diolah. (2020) 
Laju pertumbuhan ekonomi Provinsi Yogyakarta pada triwulan kedua tahun 2020 mencapai minus 6,74 persen. Apabila dilihat per kategori maka yang terkontraksi cukup dalam ada lima (5) kategori yang laju pertumbuhan ekonominya minus hingga 2 digit. Kelima kategori yaitu jasa lainnya (-42,75 persen), disusul penyediaan akomodasi makan dan minum (-39,34 persen), jasa perusahaan (-27,48 persen), kemudian kategori konstruksi (-22,18 persen) serta pertambangan dan penggalian terkontraksi 11,73 persen .

Selain merubah arah laju pertumbuhan ekonomi, ternyata pandemi covid-19 juga menggeser struktur perekonomian Provinsi Yogyakarta. Pada kondisi sebelum pandemi (Triwulan 2 Tahun 2019) struktur sektor pariwisata (masuk kategori penyediaan akomodasi makan dan minum) masih bertahan pada angka 10,91 persen (BPS Provinsi DI Yogyakarta, 2020). Ketika pandemi mulai melanda (Triwulan 2 Tahun 2020) struktur sektor pariwisata mengecil hingga 6,58 persen (BPS Provinsi D.I Yogyakarta, 2020b).

Tabel 2

Laju Pertumbuhan Ekonomi Provinsi Yogyakarta Sebelum dan Sesudah Pandemi ( y on y)

\begin{tabular}{lrr}
\hline \multicolumn{1}{c}{ Kategori/Sektor } & Sebelum Pandemi & Sesudah Pandemi \\
\hline Pertanian, Kehutanan dan Perikanan & Triwulan 2 2019 & Triwulan 2 2020 \\
Pertambangan dan Penggalian & $-0,83$ & 10,06 \\
Industri Pengolahan & 2,63 & $-11,73$ \\
Pengadaan Listrik dan Gas & 5,16 & $-7,50$ \\
Pengadaan Air, Pengelolaan Samah, Limbah dan & 4,85 & $-7,74$ \\
Daur Ulang & 8,70 & 3,16 \\
Konstruksi & & \\
Perdagangan Besar dan eceran & 18,91 & $-22,18$ \\
Transportasi dan Pergudangan & 5,28 & $-9,43$ \\
Penyediaan Akomodasi dan Makan Minum & 2,08 & $-34,30$ \\
Informasi dan Komunikasi & 7,74 & $-39,34$ \\
Jasa Keuangan dan Asuransi & 7,33 & 20,74 \\
Real Estate & 7,83 & 0,25 \\
Jasa Perusahaan & 5,03 & 2,75 \\
Administrasi Pemerintahan & 6,38 & $-27,48$ \\
Jasa Pendidikan & 8,47 & 5,02 \\
Jasa Kesehatan dan Kegiatan Sosial & 6,14 & 5,13 \\
Jasa Lainnya & 7,11 & 17,91 \\
\hline Sumber: data diolah (2020) & 5,83 & $-42,75$ \\
\hline
\end{tabular}

Sumber: data diolah. (2020)

Perubahan struktur ini karena berkurangnya jumlah wisatawan yang mengunjungi Yogyakarta. Pergeseran yang signifikan juga terjadi pada kategori informasi dan komunikasi, distribusi persentasenya hanya 7,98 persen sebelum pandemi covid-19 naik menjadi 10,29 persen pada saat pandemi (BPS Yogyakarta, 2019a). Hal ini disebabkan adanya pembatasan sosial sehingga memaksa orang untuk bekerja (Work From Home) dan belajar dari rumah 
(School From Home) dengan aplikasi daring. Maka dimanfaatkan teknologi internet untuk mengurangi interaksi dengan orang lain dengan menggunakan aplikasi zoom, video call, google meet dan sebagainya.

\subsection{Hasil Pengolahan Regresi Linier Berganda}

Penelitian ini akan mengukur korelasi sektor pariwisata yang diwakili oleh variabel TPK hotel bintang $\left(X_{1}\right)$ dan jumlah kunjungan wisatawan mancanegara $\left(X_{2}\right)$ terhadap pertumbuhan perekonomian Provinsi Yogyakarta $(\mathrm{Y})$. Hasil pengolahan regresi linier berganda dengan program SPSS menghasilkan model persamaan sebagai berikut :

$Y=-517.279+0,152 X_{1}+0,006 X_{2}+\varepsilon$

Dari model persamaan tersebut, dapat kita amati nilai konstanta adalah negatif 517.279. Ketika diasumsikan kedua variabel independen $(X)$ yaitu variabel TPK dan jumlah wisatawan mancanegara konstan maka pertumbuhan ekonomi $(Y)$ akan mengalami penurunan. Koefisien positif yang menyertai variabel independen baik TPK hotel bintang $\left(X_{1}\right)$ maupun jumlah kunjungan wisatawan mancanegara $\left(X_{2}\right)$ bersifat sejalan dengan variabel pertumbuhan ekonomi $(Y)$. Setiap kenaikan TPK hotel bintang $\left(X_{1}\right)$ akan menaikkan pertumbuhan ekonomi $(Y)$. Kenaikan itu sebesar 0,0152. Demikian halnya dengan setiap kenaikan jumlah kunjungan wisatawan mancanegara $\left(\mathrm{X}_{2}\right)$ akan menaikkan pertumbuhan ekonomi $(\mathrm{Y})$ dengan besarnya hingga 0,006 .

Tabel 3

Koefisien untuk Pembentukan Persamaan

\begin{tabular}{crrrrrrr}
\hline Model & \multicolumn{2}{c}{$\begin{array}{c}\text { Unstandardized } \\
\text { Coefficients }\end{array}$} & $\begin{array}{c}\text { Standardized } \\
\text { Coefficients }\end{array}$ & t & Sign & \multicolumn{2}{c}{ Collinearity Statistics } \\
& B & $\begin{array}{c}\text { Std } \\
\text { Error }\end{array}$ & Beta & & & Tolerance & VIF \\
\hline 1 ( Constant) & -517.279 & 149.770 & & -3.454 & 0.005 & - & - \\
\hline TPK & 0.152 & 0.066 & 0.718 & 2.299 & 0.040 & 0.170 & 5.880 \\
Wisman & 0.006 & 0.010 & 0.190 & 0.609 & 0.554 & 0.170 & 5.880 \\
\hline
\end{tabular}

Dependen Variable : Pertumbuhan Ekonomi

Sumber : data diolah. (2020)

Pada output pengolahan model summary didapatkan 80,10 persen variabel pertumbuhan ekonomi Provinsi Yogyakarta dapat dijelaskan oleh kedua variabel independen pada penelitian ini, yaitu variabel TPK $\left(\mathrm{X}_{1}\right)$ dan jumlah kunjungan wisatawan mancanegara $\left(\mathrm{X}_{2}\right)$. Sisanya sebanyak 19,90 persen dijelaskan oleh variabel lain di luar model yang sudah terbentuk.

Tabel 4

Output Pengolahan Model Summary

\begin{tabular}{cccccr}
\hline Model & $\mathbf{R}$ & R Square & $\begin{array}{c}\text { Adjusted R } \\
\text { Square }\end{array}$ & $\begin{array}{c}\text { Std.Error of the } \\
\text { Estimate }\end{array}$ & $\begin{array}{c}\text { Durbin } \\
\text { Watson }\end{array}$ \\
\hline & Beta & & & & \\
\hline 1 & 0.895 & 0.801 & 0.768 & 197.60079 & 1.200 \\
\hline
\end{tabular}

Presictors : Wisman, TPK

Dependen Variable : Pertumbuhan Ekonomi 
Sumber : data diolah. (2020)

Hasil uji pada kelima asumsi menunjukkan hal yang signifikan. Asumsi yang sudah diuji adalah sebagai berikut :

\section{Uji Normalitas}

Tabel 5

Uji Normalitas dengan Kolmogorov Smirnov Test

\begin{tabular}{|c|c|c|c|c|}
\hline Model & & $\begin{array}{l}\text { Pertumbuhan } \\
\text { Ekonomi }\end{array}$ & TPK & Wisman \\
\hline $\mathrm{N}$ & & 15 & 15 & 15 \\
\hline \multirow[t]{2}{*}{ Normal Parameters ${ }^{a . b}$} & Mean & 415.7333 & 3049.5333 & 27729.4000 \\
\hline & Std.Deviation & 409.89380 & 1939.21747 & 12984.07035 \\
\hline \multirow[t]{3}{*}{ Moat Extreme Difference } & Absolute & 0.393 & 0.364 & 0.248 \\
\hline & Positve & 0.207 & 0.221 & 0.117 \\
\hline & Negative & 0.393 & 0.364 & 0.248 \\
\hline Test Statistics & & 0.393 & 0.364 & 0.248 \\
\hline Asymp.Sig.(2 tailed) & & $0.000^{c}$ & $0.000^{c}$ & $0.014^{c}$ \\
\hline Exact Sign (2 tailed) & & 0.013 & 0.021 & 0.267 \\
\hline Point Probability & & 0.000 & 0.000 & \\
\hline
\end{tabular}

a. Test distribution is Normal

b. Calculated from Data

c. Lilliefors Significance Correction

Sumber : data diolah. (2020)

Normalitas merupakan asumsi dasar yang harus dipenuhi dalam analisis regresi linier berganda. Asumsi normalitas akan menguji apakah suatu model yang telah terbentuk datanya berdistribusi normal. Uji statistik normalitas yang sering digunakan adalah Kolmogorov Smirnov test dengan pemilihan pengolahan SPSS secara exact sign. Batasan signifikansi yang dipakai adalah 0,01 .

Pada tabel 5 variabel pertumbuhan ekonomi, variabel TPK hotel bintang $\left(\mathrm{X}_{1}\right)$ dan variabel kunjungan wisatawan mancanegara $\left(\mathrm{X}_{2}\right)$ masing masing mempunyai nilai exact sign sebesar 0,013 pada pertumbuhan ekonomi, sebesar 0,027 pada variabel TPK hotel bintang $\left(X_{1}\right)$ dan nilai exact sign 0,267 pada variabel kunjungan wisatawan mancanegara $\left(X_{2}\right)$. Nilai ketiganya di atas 0,01 . Dapat disimpulkan baik variabel dependen $(Y)$ dan independen $(X)$ pada penelitian ini bersifat normal.

\section{Uji Multikolinieritas}

Model yang baik tidak mengandung multikolinieritas. Uji ini untuk mengetahui apakah ada hubungan antar variabel independen pada sebuah model. Dengan mengamati nilai Variance Inflation Factor (VIF) dapat disimpulkan bahwa sebuah persamaan model mengandung multikolieritas atau tidak. Ketentuan uji multikolinieritas dengan membandingkan nilai VIF, apabila lebih dari 1 dan kurang dari 10 dipastikan model tidak mengandung 
multikolinieritas. Pada tabel 6 nilai VIF variabel TPK hotel bintang $\left(\mathrm{X}_{1}\right)$ dan jumlah kunjungan wisatawan mancanegara $\left(\mathrm{X}_{2}\right)$ sebesar 5,880 , artinya model tidak mengandung multikolinieritas.

\section{Uji Homoskedastisitas}

Uji Homoskedastisitas bertujuan untuk mengetahui apakah pada model regresi yang terbentuk terjadi kesamaan varians dari residual satu pengamatan ke pengamatan lain yang sifatnya sama dan tetap. Dalam pengujian ini uji homoskedastisitas menggunakan Rank Spearmen test dengan kriteria signifikansi lebih dari 0,05. Pada tabel koefisien dengan Unstandardized residual didapatkan bahwa kedua variabel independen baik TPK hotel bintang $\left(X_{1}\right)$ (signifikansi 0,635$)$ dan jumlah kunjungan wisatawan mancanegara $\left(X_{2}\right)$ (signifikansi 0,149). Kedua signifikansi di atas 0,05 (Tabel 6).

Tabel 6

Koefisien Unstandardized Residual untuk Uji Multikolinieritas dan Homoskedastisitas

\begin{tabular}{ccccccrr}
\hline Model & \multicolumn{2}{c}{$\begin{array}{c}\text { Unstandardized } \\
\text { Coefficients }\end{array}$} & $\begin{array}{c}\text { Standardized } \\
\text { Coefficients }\end{array}$ & $\mathbf{t}$ & Sign & \multicolumn{2}{c}{ Collinearity Statistics } \\
& B & $\begin{array}{c}\text { Std } \\
\text { Error }\end{array}$ & Beta & & & Tolerance & VIF \\
\hline 1 ( Constant) & 267.750 & 77.570 & & 3.452 & 0.005 & - & - \\
\hline TPK & 0.017 & 0.034 & 0.268 & 0.486 & 0.635 & 0.170 & 5.880 \\
Wisman & 0.008 & 0.005 & 0.851 & -1.543 & 0.149 & 0.170 & 5.880 \\
\hline
\end{tabular}

Dependen Variable : Abs_RES

Sumber : data diolah. (2020)

\section{Uji Autokorelasi}

Uji autokorelasi untuk mengetahui apakah dalam model regresi terdapat korelasi antara error/galat/pengganggu pada periode sekarang dengan error pada periode sebelumnya. Model yang baik tidak mengandung autokorelasi. Uji yang digunakan untuk menyelidiki suatu model regresi mengandung autokorelasi maupun tidak dengan uji runs test. Uji ini ditempuh setelah peneliti menemukan ketidakjelasan mengenai posisi model ketika menggunakan uji Durbin Watson. Nilai Asymptot sign pada uji runs test diatas sebesar 1,000. Artinya posisi model diatas signifikansi 0,05 . Hasil runs test menyatakan data yang dipergunakan cukup acak sehingga tidak terdapat masalah autokorelasi (Tabel 7).

Tabel 7

Hasil Uji Autokorelasi dengan Run Test Model Unstandardized Residual

\begin{tabular}{lr}
\hline Test Value $^{\mathrm{a}}$ & -2.23456 \\
Cases $<$ Test Value & 7 \\
\hline
\end{tabular}




\begin{tabular}{lr}
\hline Cases $>=$ Test Value & 8 \\
Total Cases & 15 \\
Number of Runs & 8 \\
Z & 0.000 \\
Asymp.Sig.(2 tailed) & 1.000 \\
\hline
\end{tabular}

a. Median

Sumber : data diolah. (2020)

Hasil pengolahan SPSS pada tabel ANOVA (Tabel 8) menyebutkan uji simultan dengan statistik uji $F$ sebesar 24,121 dengan signifikansi 0,000 (kurang dari 0,05). Maka disimpulkan bahwa kedua variabel independen baik TPK hotel bintang $\left(X_{1}\right)$ maupun jumlah kunjungan wisatawan mancanegara $\left(\mathrm{X}_{2}\right)$ bersama-sama mempengaruhi laju pertumbuhan perekonomian (Y) Provinsi Yogyakarta (hipotesis kedua terjawab).

Tabel 8

Hasil Uji Simultan

\begin{tabular}{cllllc}
\hline Model & Sum of Squares & df & $\begin{array}{c}\text { Mean } \\
\text { Square }\end{array}$ & & Uji F \\
\hline & & & & F & Sign \\
\hline 1 Regression & 1883628.058 & 2 & 941814.029 & 24.121 & $0.000^{\mathrm{b}}$ \\
Residual & 468552.875 & 12 & 39046.073 & & \\
Total & 23521180.933 & 14 & & & \\
\hline
\end{tabular}

a. Dependent Variable : Pertumbuhan Ekonomi

b. Predictors : Wisman, TPK

Sumber : data diolah. (2020)

Sedangkan uji parsial uji t (Tabel 9) menyebutkan variabel TPK hotel bintang $\left(X_{1}\right)$ memiliki signifkansi 0,040 (masih di bawah 0,05) dan variabel jumlah kunjungan wisatawan mancanegara $\left(X_{2}\right)$ signifikansinya sebesar 0,554. Artinya hipotesis ketiga terpenuhi, bahwa secara parsial hanya TPK hotel bintang $\left(X_{1}\right)$ yang berpengaruh terhadap laju pertumbuhan ekonomi Provinsi Yogyakarta sedangkan variabel jumlah kunjungan wisatawan mancanegara $\left(\mathrm{X}_{2}\right)$ tidak berpengaruh secara parsial terhadap pertumbuhan ekonomi Provinsi Yogyakarta.

Tabel 9

Hasil Uji Parsial

\begin{tabular}{|c|c|c|}
\hline \multirow[t]{2}{*}{ Model } & \multicolumn{2}{|c|}{ Uji t } \\
\hline & $t$ & Sign \\
\hline 1 (Constant) & -3.454 & 0.005 \\
\hline TPK & 2.299 & 0.040 \\
\hline Wisman & 0.609 & 0.554 \\
\hline
\end{tabular}


Sumber : data diolah. (2020)

\subsection{Analisis Deskriptif Kuantitatif}

Dampak yang dirasakan oleh sektor pariwisata terhadap perekonomian Provinsi Yogyakarta juga akan mempengaruhi denyut nadi UMK. Tujuan utama orang berkunjung ke Provinsi Yogyakarta adalah untuk berwisata dan melanjutkan pendidikan. Ketika berwisata, pengunjung akan mencari oleh-oleh dan cinderamata yang akan dibawanya pulang ke tempat asal. Sedangkan oleh-oleh dan cinderamata sebagian besar dihasilkan oleh UMK.

UMK berupa industri makanan dan minuman yang tumbuh menjamur sekitar tempat wisata dan sentra pendidikan seperti tempat kuliah dan bimbingan belajar terimbas selama pandemi covid19. Dimasa pandemi kebijakan School From Home (SFH) atau belajar secara daring menyebabkan mahasiswa mengurungkan niatnya untuk berangkat ke Yogyakarta. Akibatnya banyak UMK yang mengalami penurunan pendapatan bahkan ada yang gulung tikar. Demikian juga dengan pembatasan sosial dan travelling menyebabkan hotel dan tempat wisata sepi.

Padahal dari hasil listing Sensus Ekonomi 2016 (SE-2016) yang diselenggarakan oleh Badan Pusat Statistik tercatat jumlah UMK mencapai 524,9 ribu atau hampir 98,36 persen dari total usaha non pertanian di Daerah Istimiewa Yogyakarta. Dengan angka sebesar itu, secara ekonomi UMK mampu menyerap tenaga kerja lebih dari 1.044,5 ribu orang atau sekitar 78,98 persen dari tenaga kerja pada kategori non pertanian (BPS Yogyakarta, 2017). Apabila UMK tutup akan terjadi pengangguran dalam skala besar dan hal tersebut berdampak pada pertumbuhan ekonomi.

Struktur perekonomian Yogyakarta cukup unik karena ditopang oleh industri pengolahan (12,82 persen). Disusul sektor konstruksi sebesar 11,14 persen, dan rangking ketiga sektor pariwisata yang masuk dalam kategori penyediaan akomodasi makan dan minum sebesar 10,37 persen (BPS Yogyakarta, 2019a). UMK dalam penghitungan PDRB masuk kategori industri pengolahan.

Apabila dilihat ke dalam lagi, maka dapat dilihat bahwa industri makanan dan minuman paling dominan (56,43 persen) menguasai industri di Provinsi Yogyakarta (Gambar 2). Hal ini karena Yogyakarta menawarkan wisata kuliner, beragam oleh-oleh berupa makanan kepada para wisawatan yang berkunjung. Nama gudeg, bakpia, coklat monggo, tasuba, jogja scrummy dan solok pondok tidak terasa asing bagi yang pernah mengunjungi Yogyakarta. Semua cinderamata diatas bisa kita temui dengan mudah di Kota Yogyakarta, dan rata-rata usahanya bersifat UMK. 


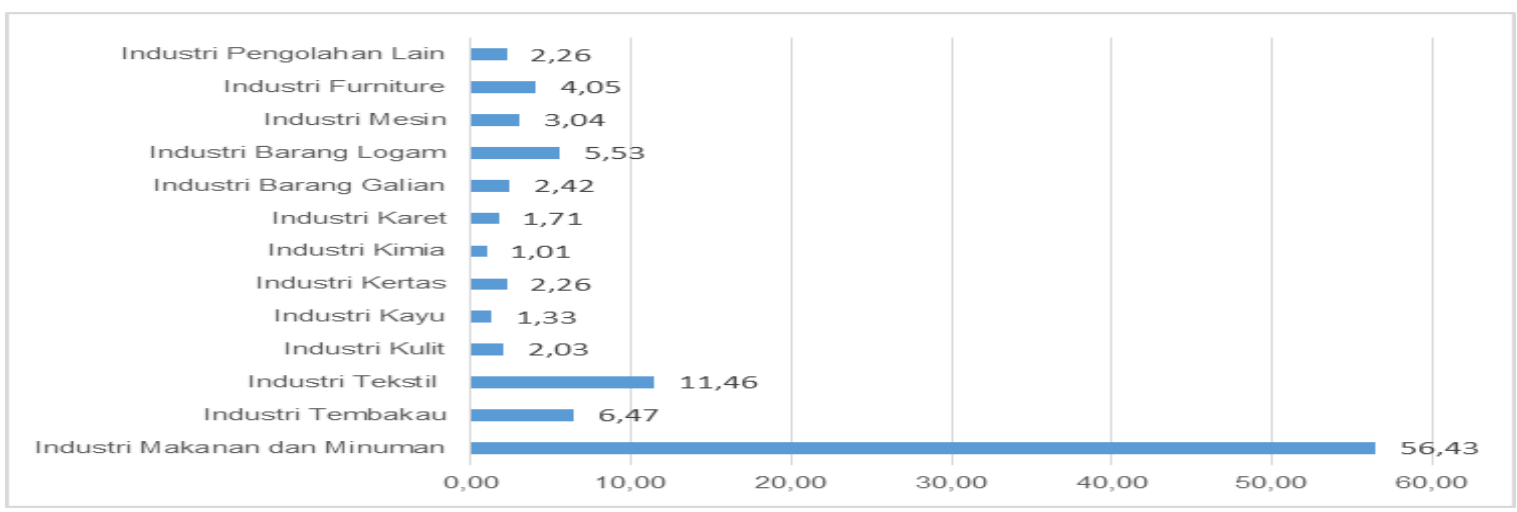

Gambar 2

Persentase Industri menurut Sub Kategori di Yogyakarta, 2019

Sumber: data diolah, 2020

Publikasi Profil Industri Mikro dan Kecil Daerah Istimewa Yogyakarta tahun 2019 menyebutkan bahwa Yogyakarta ditunjang oleh UMK sebesar 75,09 persen yang berada di sekita usaha wisata. Berdasarkan survei IMK Tahunan 2019 terdapat 61,19 ribu industri makanan (KBLI 10) atau 41,73 persen. Ada sekitar 22,27 ribu industri barang anyaman dari bambu, rotan dan sejenisnya (KBLI 16) yang biasanya berupa kerajinan sebagai cinderamata dari Yogyakarta (sebesar 15,18 persen). Sedangkan industri pakaian jadi (KBLI 14) berada pada urutan ketiga berupa kerajinan batik sebanyak 19,09 ribu usaha atau 13,02 persen (BPS Yogyakarta, 2019b).

Batik Yogyakarta terkenal karena motifnya berbeda dengan daerah lain. Motif batik Yogyakarta sarat makna, sehingga batik menjadi oleh-oleh yang wajib dibawa oleh wisatawan. Banyaknya kain batik yang dibeli oleh wisatawan mampu menghidupkan industri tekstil Yogyakarta yang sebagian besar berbentuk UMK.

Ketika pandemi covid-19 melanda, sektor pariwisata seolah berhenti. Kebijakan pembatasan sosial dan travelling yang ditetapkan pemerintah pusat membuat tempat pariwisata sepi pengunjung dan hal tersebut berdampak pada pendapatan UMK. Pelaku UMK mengalami penurunan pendapatan hingga 80 persen (Berita satu.com, 2020). Padahal total usaha pendapatan UMK di Yogyakarta tahun 2019 mencapai 14 triliun lebih. Apabila diurutkan menurut proporsinya maka industri makanan menempati posisi tertinggi dengan porsi 38,40 persen, disusul industri furnitur 12,99 persen dan industri pakaian jadi 10,46 persen (BPS Yogyakarta, 2019b)

Walaupun demikian, UMK dianggap mampu bertahan pada berbagai krisis, semoga juga ketika pandemi covid-19 menerpa Yogyakarta. Sedikitnya ada tiga alasan kenapa UMK bisa bertahan dalam krisis. Pertama, UMK menghasilkan barang dan jasa yang dekat dengan kebutuhan masyarakat. Kedua, bahan baku/sumber daya UMK lebih memberdayakan bahan lokal ketimbang impor baik sumber daya manusia, modal, bahan baku utama maupun peralatan. Jadi, ketika pandemi covid-19 datang, UMK masih hidup walaupun dengan kondisi 
yang jauh dari kemakmuran, mereka bertahan dengan mengandalkan konsumsi penduduk asli Yogyakarta.

\section{Kesimpulan}

Dari hasil pengolahan analisis dengan uji statistik Mc Nemar, analisis regresi berganda dan analisis deskriptif kuantitatif terhadap pertumbuhan perekonomian, sektor pariwisata dan UMK di Provinsi Yogyakarta maka dapat disimpulkan :

1. Hasil uji statistik Mc Nemar mendapatkan angka signifikansi 0,021. Artinya pandemi covid-19 secara statistik memang berpengaruh terhadap perekonomian Provinsi Yogyakarta. Hal ini menjawab hipotesis pertama. Uji Statistik Mc Nemar juga menyimpulkan ada 9 kategori dalam PDRB lapangan usaha Provinsi Yogyakarta yang tumbuh negatif setelah pandemi covid19 melanda dan hanya satu kategori yang tumbuh positif setelah pandemi. Selain mengubah arah laju pertumbuhan ekonomi, pandemi covid-19 juga merubah struktur kategori penyediaan akomodasi makan dan minum hingga turun 6,58 persen karena pembatasan sosial. Sedangkan kategori informasi dan komunikasi meningkat menjadi 10,29 persen akibat diberlakukannya Work From Home (WFH) dan School From Home (SFH).

2. Hasil analisis regresi linier berganda menyimpulkan sektor pariwisata berpengaruh terhadap perekonomian Provinsi Yogyakarta. Dari hipotesis kedua dan ketiga diperoleh bahwa secara simultan variabel TPK hotel bintang $\left(\mathrm{X}_{1}\right)$ dan jumlah kunjungan wisatawan mancananegara $\left(X_{2}\right)$ yang mewakili sektor pariwisata berpengaruh signifikan terhadap pertumbuhan ekonomi di Yogyakarta. $R$ square sebesar 0,801 menjelaskan bahwa sebanyak 80,10 persen variabel pertumbuhan ekonomi mampu dijelaskan oleh TPK hotel bintang $\left(\mathrm{X}_{1}\right)$ dan jumlah kunjungan wisatawan mancananegara $\left(X_{2}\right)$ di Yogyakarta. Sedangkan secara parsial hanya TPK hotel bintang $\left(X_{1}\right)$ yang berpengaruh.

3. Analisis deksriptif kuantitatif melengkapi informasi bahwa sektor pariwisata memang berperan penting dalam eksistensi UMK. Data dari publikasi Profil Industri Mikro dan Kecil Daerah Istimewa Yogyakarta tahun 2019 menyebutkan terdapat 61,19 ribu industri makanan (KBLI 10). Ada sekitar 22,27 ribu usaha barang anyaman dari bambu, rotan dan sejenisnya (KBLI 16) yang biasanya berupa kerajinan sebagai cinderamata dari Yogyakarta. Sedangkan industri pakaian jadi (KBLI 14) berupa kerajinan batik sebanyak 19,09 ribu usaha (Berdasarkan survei Industri Mikro Kecil Tahunan 2019). Sehingga ketika sektor pariwisata terganggu oleh pandemi covid-19 akan mempengaruhi kehidupan UMK di Yogyakarta. Penelitian ini hanya kajian pengantar (early warning) bahwa pandemi covid-19 yang berdampak pada pertumbuhan ekonomi dan sektor pariwisata juga akan berefek pada kelangsungan hidup UMK.

Perlu penelitian lebih mendalam mengenai dampak pandemi covid-19 terhadap pariwisata dan perekonomian Yogyakarta dan efeknya bagi UMK sehingga dapat dicari solusi agar UMK 
bisa bertahan di tengah pandemi covid-19.. Penelitian bisa diperluas dengan mengkaitkannya dengan sektor lain seperti transportasi dan jasa lainnya yang berada di sekitar sektor pariwisata. Bisa dilakukan juga kajian mengenai kesulitan apa saja yang dialami oleh UMK dan menelusuri akar permasalahan agar mereka bisa bertahan selama pandemi covid-19. Semoga pandemi covid-19 segera berlalu.

\section{Daftar Pustaka}

A. Masatip. (2020). Marketing Strategy Analysis of the Inna Parapat Hotel in a Covid-19 Pandemic Situation. Jurnal Akademi Pariwisata Medan, 8(2).

Akouino, C. (2013). Analisis Penyerapan Tenaga Kerja Sektor Pariwisata (Sektor Perdagangan, Hotel Dan Restoran) Di Kota Batu. Jurnal Ekonomi Pembangunan, 11(2), 154. https://doi.org/10.22219/jep.v11i2.3737

Alwandi, M. A., \& Muchlisoh, S. (2021). Karakteristik Pertumbuhan Ekonomi Dan Sektor Basis Provinsi Di Indonesia Pada Masa Pandemi Covid-19. Seminar Nasional Official Statistics, 2020(1), 82-90. https://doi.org/10.34123/semnasoffstat.v2020i1.516

Audy, A. P., \& Irfan, M. (2021). Strategi Pengelolaan Konflik Perusahaan Transportasi Darat BUMN Di Masa Pandemi Covid-19: Studi Kasus PT Kereta Api Indonesia Dalam Penerapan PSBB Jilid II. Jurnal Kolaborasi Resolusi Konflik, 3(1), 25. https://doi.org/10.24198/jkrk.v3i1.31970

Berita satu. com (2020), Dampak Covid-19, Pendapatan UMK di DIY turun 80 Persen. Diakses dari : https://www.beritasatu.com/nasional/655435/dampak-covid19-pendapatan-UMKM-didiy-turun-80

Badan Pusat Statistik (2020). Diakses pada 18 Juni 2021, dari laman : https://www.bps.go.id/subject/16/pariwisata.html

Badan Pusat Statistik (2020). Diakses pada 18 Juni 2021, dari laman : https://sirusa.bps.go.id/sirusa/index.php/indikator/60

Badan Pusat Statistik (2020). Diakses pada 18 Juni 2021, dari laman : https://sirusa.bps.go.id/sirusa/index.php/variabel/1435\#

Besra, E. (2012). Potensi Wisata Kuliner Dalam Mendukung Pariwisata Di Kota Padang. Jurnal Riset Akuntansi Dan Bisnis, 12(1), 74-101.

BPS Provinsi D.I Yogyakarta. (2020a). Berita Resmi Statistik: Perkembangan Pariwisata dan Transportasi Udara Daerah Istimewa Yogyakarta Februari 2020. Yogyakarta.bps.go.id, 48, 1-8.

BPS Provinsi D.I Yogyakarta. (2020b). Pertumbuhan Ekonomi DIY Triwulan II-2020. 051, 1-16. https://yogyakarta.bps.go.id/pressrelease/2020/08/05/1028/pertumbuhan-ekonomi-diytriwulan-ii-2020.html 
BPS Provinsi DI Yogyakarta. (2020). Berita Resmi Statistik. Agustus, 1-16. https://yogyakarta.bps.go.id/pressrelease/2019/11/01/375/tingkat-penghunian-kamar--tpk-hotel--berbintang-pada-bulan-september-2019-mencapai-58-97-persen.html

BPS Provinsi DIY Yogyakarta. (2020). Berita Resmi Statistik. Mei, 16. https://yogyakarta.bps.go.id/pressrelease/2019/11/01/375/tingkat-penghunian-kamar--tpk-hotel--berbintang-pada-bulan-september-2019-mencapai-58-97-persen.html

BPS Yogyakarta. (2017). Potensi Usaha Mikro Kecil Provinsi Yogyakarta.

BPS Yogyakarta. (2019a). Produk Domestik Regional Bruto Daerah Istimewa Yogyakarta Menurut Lapangan Usaha.

BPS Yogyakarta. (2019b). Profil Industri Mikro dan Kecil Tahun 2019.

Djausal, G. P., Larasati, A., \& Muflihah, L. (2020). Strategi Pariwisata Ekologis Dalam Tantangan Masa Pandemik Covid-19. Jurnal Perspektif Bisnis, 3(1), 57-61. https://doi.org/10.23960/jpb.v3i1.15

Faelasofi, R. (2017). Identifikasi Kemampuan Berpikir Kreatif Matematika Pokok Bahasan Peluang. JURNAL E-DuMath, 3(2), 155-163. https://doi.org/10.26638/je.460.2064

Gaol, D. F. L. (2003). The Model of Japan and the Philippines Cooperation in the Field of Employment. 1-16.

Gössling, S., Scott, D., \& Hall, C. M. (2020). Pandemics, Tourism and Global Change: a Rapid Assessment of COVID-19. Journal of Sustainable Tourism, 29(1), 1-20. https://doi.org/10.1080/09669582.2020.1758708

Kalebos, F. (2016). Faktor Faktor Yang Mempengaruhi Kepuasan Wisata yang Berkunjung ke Daerah Wisata Kepulauan. Jurnal Riset Bisnis Dan Manajemen, 4, 489-502.

Kusuma, I. D. G. (2020). Wacana Pariwisata Bali dalam Pusaran Pandemi Covid-19. Jurnal Cakrawarti, 2(2), 40-47.

Maulana, A. (2016). Pengaruh Kunjungan Wisatawan Mancanegara dan Perjalanan WIsatawan Nusantara Terhadap Penyerapan Tenaga Kerja Sektor Pariwisata di Indonesia. Jurnal Kepariwisataan Indonesia, 11(1), 119-143.

Munanda.R, A. . (2019). Pengaruh Kunjungan Wisatawan Mancanegara, Rata-Rata Pengeluaran Dan Tingkat Hunian Hotel Terhadap Pendapatan Indonesia Pada Sektor Pariwisata. Jurnal Kajian Ekonomi Dan Pembangunan, 1(1), 37-48.

Ningsih, S., \& Dukalang, H. H. (2019). Penerapan Metode Suksesif Interval pada Analisis Regresi Linier Berganda. Jambura Journal of Mathematics, 1(1), 43-53. https://doi.org/10.34312/jjom.v1i1.1742

Pak, A., Adegboye, O. A., Adekunle, A. I., Rahman, K. M., McBryde, E. S., \& Eisen, D. P. (2020). Economic Consequences of the COVID-19 Outbreak: the Need for Epidemic Preparedness. Frontiers in Public Health, 8(May), 1-4. 
https://doi.org/10.3389/fpubh.2020.00241

Putra, I. G. A. A. S., \& Saskara, I. A. N. (2013). Efektivitas Dan Dampak Program Bantuan Kredit Usaha Rakyat (KUR) Terhadap Pendapatan Dan Kesempatan Kerja Usaha Mikro Kecil Dan Menengah (UMKM) Di Kota Denpasar. E-Jurnal EP Unud, 2(10), 457-468.

Sakhibul, A. (2017). Pengaruh Pariwisata Terhadap Pertumbuhan Ekonomi Di Kota Sabang. Jurnal Ekonomi Dan Kebijakan Publik Indonesia, 4(1), 13-22.

Sanaubar, G., Hidayat, W., \& Kusuma, H. (2017). Pengaruh Potensi Pariwisata Terhadap

Penyerapan Tenaga Kerja Sektor Perhotelan Di 9 Kabupaten/Kota Provinsi Jawa Timur Tahun 2012-2015. Jurnal Ilmu Ekonomi, 1(3), 324-339. http://202.52.52.22/index.php/jie/article/view/6158

Saputra, A. K., \& Kurniawan, A. (2012). Peran Sektor Pariwisata Dalam Perekonomian Wilayah

Provinsi Daerah Istimewa Yogyakarta. Jurnal Bumi Indonesia, 1(2), 19-26. http://lib.geo.ugm.ac.id/ojs/index.php/jbi/article/download/3/3

Sari, A. N., \& Aliyah, I. (2021). Daya Tarik Kampung Ketandan Yogyakarta sebagai Wisata Budaya bagi Generasi Milenial. Jurnal Pariwisata Dan Budaya, 22(4).

Sugiyanto. (2004). Yogyakaria Kota Pendidikan Dan Ekonomi Alternatif. Jurnal Cakrawala Pendidikan, 3(3), 523-547. https://doi.org/10.21831/cp.v3i3.7594

Sunaryo, N. ., Putra, I. N. ., \& Dewi, M. H. . (2019). Perkembangan Wisata Belanja Oleh-Oleh Makanan di Kota Malang. Jumpa, 6(1), 26-47. http://digilib.iainpalangkaraya.ac.id/449/6/File 3 BAB II Landasan Teori.pdf

Supriyadi, E. A., Supartono, W., Supriyadi, E. A., Supartono, W., Teknologi, D., Pertanian, I., Pertanian, F. T., \& Mada, U. G. (2020). Pengembangan Strategi Bisnis Restoran Segmen Atas di Yogyakarta dengan Pendekatan Critical Success Factors. Jurnal Teknologi Industri Pertanian, 30(3), 265-270. https://doi.org/10.24961/j.tek.ind.pert.2020.30.3.265

Suryadinata, A. (2017). Nasional dan Call for Paper (Issue 20).

Tang, C. F., \& Tan, E. C. (2015). Does Tourism Effectively Stimulate Malaysia's Economic Growth?. Tourism Management, 46, 158-163

Wahdini, R., Tandililing, E., \& Mursyid, S. (2009). Remediasi Miskonsepsi Menggunakan LKPD Berbasis Crossword Puzzle Materi. Jurnal Pendidikan Dan Pembelajaran Khatulistiwa, $7(9), 1-10$.

Windayani, I., \& Sri Budhi, M. (2017). Pengaruh Kunjungan Wisatawan, Tingkat Hunian Hotel, Pengeluaran Wisatawan Terhadap Penyerapan Tenaga Kerja Dan Pertumbuhan Ekonomi Di Provinsi Bali. E-Jurnal Ekonomi Pembangunan Universitas Udayana, 6(2), 195-224.

Yane, S., Arifin, Z., \& Fuzita, M. (2017). Analisis Tingkat Kesegaran Jasmani Mahasiswa Program Studi Penjas IKIP PGRI Pontianak. Jurnal Pendidikan Olahraga, 6(1), 1-9.

Yuliana. (2017). Pemberdayaan dalam Peningkatan Ekonomi Masyarakat di Lingkungan Objek 
Wisata Ikan Sakti Sungai Jainah. UNES Journal of Community Service, 2(2), 157-163. 